\title{
DESCRIÇÃO DA FÊMEA DE ONEGA BRACTEATA YOUNNG (HOMOPTERA, CICADELLIDAE, CICADELLINAE) ${ }^{1}$
}

\author{
Rodney Ramiro Cavichioli ${ }^{2}$ \\ Márcia Regina Wyler ${ }^{2,3}$
}

\begin{abstract}
The female of Onega bracteata Young, 1977 is described by once first. The specimen was colleting in Peru.

Key words. Onega, Cicadellinae, Cicadellidae, Homoptera
\end{abstract}

Young (1977) ao descrever Onega bracteata, só possuia espécimes machos. Ao recebermos um espécime fêmea de Onega oriundo do Peru, enviado pelo Dr. Pedro Lozada da Universidade de São Marcos, constatamos que se tratava de $O$. bracteata, por comparação com o holótipo. Damos, a seguir, a sua descrição.

\section{Onega bracteata Young, 1977}

Figs 1-5

Onega bracteata Young, 1977: 286

Medidas (em mm) macho/fêmea: comprimento total: 13,77/14,86; comprimento mediano da cabeça: $0,76 / 0,84$; distância transocular: 2,36/2,72; comprimento mediano do pronoto: 1,64/2,08; distância entre os umêros: $3,08 / 3,56$; comprimento das tégminas: 10,83/12,67; largura das tégminas: 2,67/3,12.

Material examinado: Holótipo macho. Callonga; Paucartambo Prov.; Dept. Cuzco, Peru/19.ii.1952; F.L. Woytrowski/HOLOTYPE; Onega bracteata; D.A. Young/USNM.

EQUADOR. Azuay. Cuenca, El Cajas, Yacutuviana, ix/1983, 2400m, (R. Madfield), 1 macho, B.M. 1984-24.

PERU. Junín. San Ramon (1-3 km) (Mina Pichita) 2100m, 23/vii/88, (P. Lozada), 1 fêmea [MHNSM].

Descrição: fêmea. Cabeça levemente pronunciada, com comprimento mediano aproximadamente $3 / 10$ da distância transocular e aproximadamente $1 / 2$ da interocular, com a margem anterior arredondada, com carena na transição entre a coroa e a face, superfície dorsal lisa e côncava; ocelos proeminentes, posicionados sobre a linha imaginária que tangencia os bordos anteriores dos

1) Contribuição número 775 do Departamento de Zoologia, Universidade Federal do Paraná.

2) Departamento de Zoologia, Universidade Federal do Paraná, Caixa Postal 19020, 81531-970 Curitiba, Paraná, Brasil.

3) Bolsista de Iniciação Científica. 


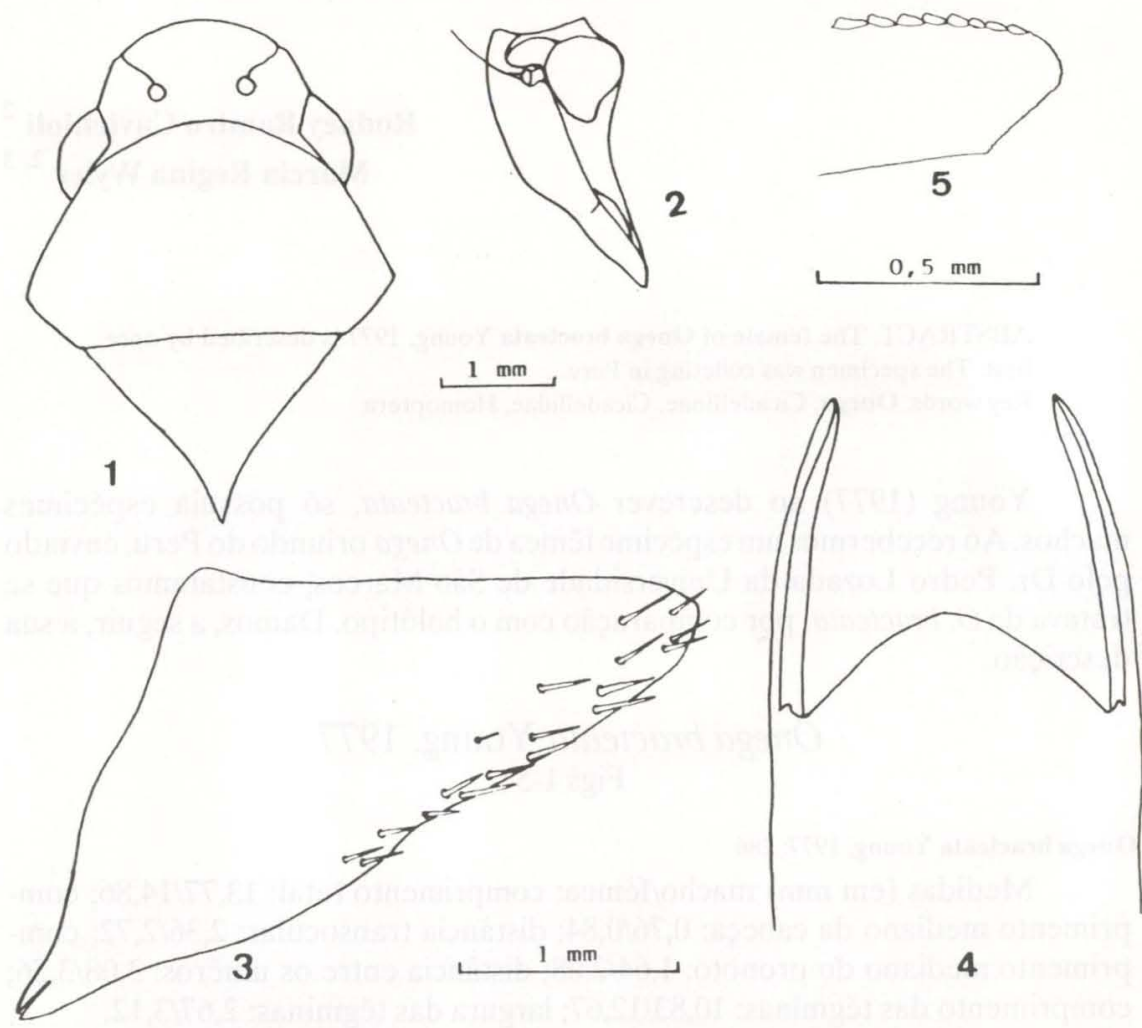

Fig. 1-5. Onega bracteata. (1-2) Holótipo. (1) Cabeça, pronoto e escutelo em vista dorsal; (2) cabeça em vista lateral; (3) pigóforo da fêmea em vista lateral; (4) placa subgenital da fêmea em vista ventral; (5) ápice da segunda valva do ovipositor em vista lateral.

olhos; lóbulos suprantenais, em vista dorsal, fortemente proeminentes, em vista lateral, oblíquos, convexos e carenados; clípeo, em vista frontal, com uma concavidade mediana, de perfil levemente convexo, sem uma angulação no terço apical; sutura transclipeal incompleta; anteclípeo de perfil contínua ao ápice do clípeo, com a margem apical convexo. Pronoto mais largo do que a cabeça, com comprimento mediano aproximadamente $3 / 5$ da distância entre os úmeros, com as margens laterais convergentes anteriormente, margem posterior mais ou menos reta, superfície dorsal lisa; tégminas de comprimento superior a cinco vezes à sua largura; venação distinta, com veias não elevadas, sem plexo de veias anteapicais, veias extranumerárias ausentes no cório e no clavo; com quatro células apicais, base da quarta célula apical mais proximal à base da terceira e com três células anteapicais fechadas; superfície das tégminas lisa; asas pos- 
teriores com $\mathrm{S}_{1+2}$ incompleta; pernas posteriores com a junção fêmur-tíbia atingindo a base do proepímero, quando em repouso; fórmula setal dos fêmures posteriores 2.1.1; basitarsos posteriores com comprimento maior do que a soma dos dois mais distais e superfície plantar com fileiras de microcerdas.

Genitália. Pigóforo mais longo do que sua largura basal, com a margem posterior levemente angulada, com macrocerdas distribuídas ao longo da margem posterior; placa subgenital alongada, com a margem posterior arredondada, com duas projeções laterais, delgadas, pontiagudas, de comprimento aproximadamente igual a largura basal da placa; segunda valva do ovipositor com o ápice voltado para baixo e margem ápico-ventral côncava.

AGRADECIMENTOS. Agradecemos, pelo empréstimo de material, ao Dr. Henry Thomas do United States National Museum de Washington; ao Dr. Mick Webb do Natural History Museum, Londres e ao Dr. Pedro Lozada da Universidad de San Marcos do Peru.

\section{REFERÊNCIAS BIBLIOGRÁFICAS}

YOUNG, D.A. 1977. Taxonomic study of the Cicadellinae (Homoptera, Cicadellidae), Part 2. New World Cicadellini and the genus Cicadella. Tech.Bull. 239: 1135 p.

Recebido em 02XI.1992; aceito em 07.Vl.1993. 